\title{
流水中に瞬間的に投下された重い流体塊 \\ の流動・拡散現象に関する実験的研究 \\ EXPERIMENTAL INVESTIGATION ON MOTION \\ OF DENSE CLOUD IN UNIFORM AMBIENT FLOW
}

\author{
秋山 壽一郎 ${ }^{1} \cdot$ 浦 勝 ${ }^{2} \cdot$ 応 新亜 $^{3} \cdot$ 西森 秀樹 $^{4}$ \\ Juichiro AKIYAMA,Masaru URA,Xinya YING and Hideki NISHIMORI \\ ${ }^{1}$ 正会員 Ph.D. 九州工業大学助教授 工学部建設社会工学科（テ804北九州市戸㚼区仙水町1-1） \\ ${ }^{2}$ 正会員 工博 九州工業大学教授 工学部建設社会工学科（同上） \\ 学生員 九州工業大学大学院 工学研究科博士後期锞程 (同上) \\ 4学生員 九州工業大学大学院 工学研究科博士前期橦程 (同上)
}

\begin{abstract}
Flow characteristics of conservative two-dimensional dense cloud released instantaneously from water surface into a well-mixed ambient fluid with uniform velocity are investigated experimentally. A series of laboratory experiments is conducted to understand flow mechanism and to obtain flow characteristics of the considering flow. It is found that dense cloud is advected in the horizontal direction at the nearly same speed as uniform flow velocity and is descent in the vertical direction in a similar manner to that in a quiescent fluid, and that the behaviour of dense cloud in a uniform flow is somewhat different from those in a quiescent fluid because weaker recirculating motion is formed as the existence of uniform flow.
\end{abstract}

Key Words : density current, vertical free thermal, integral model, experiment

\section{1.はじめに}

関西国際空港の例に見られるように、近年、水深 10～20m程度の沖合いに海上空港、物流ターミナ ル、発電所などを利用目的とする人工島の造成が計 画・施工されるようになって来ている。その際、経 済性を考慮して、底開バージによる土砂直投工が通 常用いられている。しかし、值投工では多量の土砂 が水面付近から投入されるため、微細土粒子による 大規模な污濁が発生し水産資源をはじめとする水性 生物に甚大な被害をもたらすことが大きな社会問題 となっている。

このような土砂投下問題を対象として、静水中に 瞬間的に投下された粒子群の落下挙動特性について 調べた研究は数多くある。例えば、玉井ら゙はある 与えられた水深では粒径が大きく投下量が少ない場 合には、個々の粒子の自由沈降的な落下形態となり、 粒径が小さく投下量が多い場合には、粒子群として 流動する乱流サーマル的な落下形態となることを実 験的に明かにした上で、Baines and Hopfinger ${ }^{2)}$ による単相乱流サーマル理論と実験値との比較検討
を行なうとともに、乱流サーマル理論を発展させる ことにより、自由沈降的落下挙動と乱流サ一マル的 落下挙動を統一的に説明するための固液混相の理論 モデルを提案している。玉井らの理論モデルは Escudier and Maxworthy ${ }^{3}$, Baines and Hopfinger $^{2}$ などによる一連の乱流サーマルに関す る研究の延長線上にあるが、乱流サーマル理論を混 相流に発展させたところに特徴ぶある。一力、小田 ら ${ }^{4}$ は、粒子・粒子間および粒子・流体間の相互作 用を考虑した数值シミュレーション(DEMAC法)を 開発し、静水中における粒子群の沈降挙動をパラメ トリックに解析することによって、投入粒子量や投 入容器の開屝速度などの投入条件が粒子群の沈降・ 分散挙動および水底における堆積形状に及ぼす影響 について検討を加え、粒子群の沈降挙動の解明には 周囲流体の運動を考虑する必要性を指摘している。

さて、近年このような土砂投下工事はますます大 型化するとともに、より沖合いの大水深・強潮流下 で施工される傾向にあり、様々な流動場における投 下土砂の流動・拡散・堆積現象の水理学的特性を解 明する必要があると考えられる。ところが、周囲流 
動場が落下粒子群に及ぼす影響について論じた研究 は数少なく、小田ららの研究以外には見当たらない。 小田ら ${ }^{5)}$ は先に開発したDEMAC法を用いて対数則 に従う流水の中に投下された粒子群の運動を解析し、 周围流速が粒子群の沈降・分散挙動および堆䅡形状 に及ぼす影響について検封を加え、粒子群の沈降速 度や搪がり幅が流速によって複雑に変化するにも拘 わらず、粒子群は水平方向にほぼ一定の速度で移動 することや堆積形状の予測については流速の影響を 十分に考慮する必要があることなどを指摘している。 しかし、得られた知見は意義深いものであるが、数 值実験による結果であり実験的榆証に裹付けられた ものではない。

本研究は、土砂投下にともなう微細土粒子の水質 污染問題を対象として、一様流中での澏水塊の流動・ 抬散・堆積過程の解明を目標とするものであるが、 そのためには、そのような流動特性の解明の基本と なる最も単純な流動形態である一様流水中に瞬間的 に投下された重たい流体塊の流動・抎散過程につい て十分に理解しておくことが重要であると著者らは 考える。本論文は、このような立場から重い流体塊 の流動・拡散過程について実験的に検討を加えると ともに、形状の相似形に基づくサーマル理論が対象 とする現象に適用できるかどうかについて検討を加 えたものである。

\section{2. 実験装置および方法}

図1に示す大型水槽(長さ $9.0 \mathrm{~m}$ 、樑さ $1.22 \mathrm{~m}$ 、幅 $0.6 \mathrm{~m})$ 内部に一様流発生装置を取りつけた両面アク リル製の水槽(長さ $4.0 \mathrm{~m}$ 、哚さ $1.0 \mathrm{~m}$ 、幅 $0.1 \mathrm{~m}$ )を設 置し、一様流速Uの密度 $\rho_{\mathrm{a}}$ の周囲流体中にホッパ を模した投下装置からウラニン色素で着色した所定 の浱度の砂糖を加えた初期密度 $\rho$ 。の塩水を初期単 位幅体積 $\mathrm{A}_{0}$ で水表面より瞬間的に流入させ、塩水塊 を形成させた。このようにして形成された塩水塊の 流動状況をVTRカメラを移動させながら水楷側面 より撮影を行なった。その際、塩水塊の軌跡をあら かじめ予備実験で求め、その軦跡に沿ってカメラを 移動させた。高性能VTRに収録された画像を市販 の画像解析ソフトを用いて解析することにより、塩 水塊重心の水平移動速度 $\mathrm{V}_{\mathrm{x}}$ 、落下速度 $\mathrm{V}_{\mathbf{z}}$ および形 状を求めた。流れの再現性は比較的良好であったの で、同一条件下で3回の繰り返し実験を行ない、デー 夕の信頼性を高めた。なお、重心の位置は塩水塊内 部の密度を一様と仮定して求めた。

実験条件は、表1に示すように静水中では3 通り の初期相対密度差 $\varepsilon_{0}\left(=\left(\rho_{0}-\rho_{\mathrm{a}}\right) / \rho_{\mathrm{a}}\right)$ に対して、初期 総有効重力 $W_{0}\left(=\varepsilon_{0} A_{0} g\right)$ が 3 通りになるように初期単 位幅体積 $A_{0}$ を3通りに変化させた。ここに、gは重 加速度である。一方、流水中では、2通りの $\varepsilon_{0} に$ 対

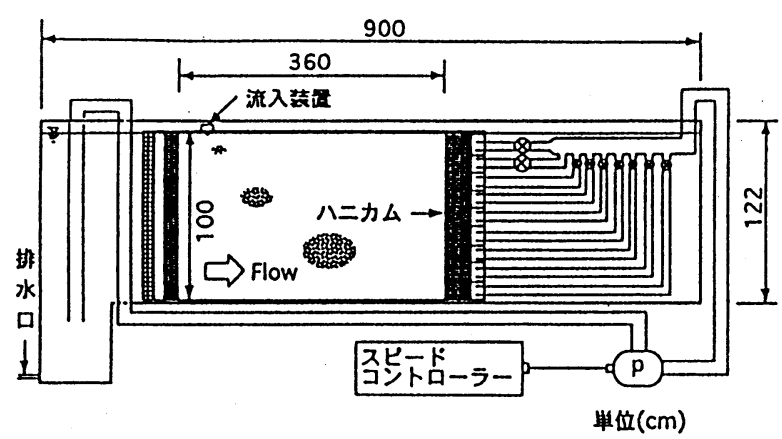

図-1 実験装置

表-1 実験条件

\begin{tabular}{|c|c|c|c|c|}
\hline \multicolumn{5}{|c|}{ 髅水中の実検条件 } \\
\hline & $\varepsilon_{0}$ & $\mathrm{U}(\mathrm{cm} / \mathrm{s})$ & $W_{0}\left(\mathrm{~cm}^{3} / \mathrm{s}^{2}\right)$ & $A_{0}\left(\mathrm{~cm}^{2}\right)$ \\
\hline case1 & \multirow{3}{*}{0.26} & 0 & 101.92 & 0.40 \\
\hline case2 & & 0 & 146.51 & 0.58 \\
\hline case3 & & 0 & 191.10 & 0.75 \\
\hline case4 & \multirow{3}{*}{0.32} & 0 & 101.92 & 0.33 \\
\hline case5 & & 0 & 148.96 & 0.48 \\
\hline case6 & & 0 & 196.00 & 0.63 \\
\hline case7 & \multirow{3}{*}{0.38} & 0 & 102.41 & 0.28 \\
\hline case8 & & 0 & 148.96 & 0.40 \\
\hline case9 & & 0 & 195.51 & 0.53 \\
\hline \multicolumn{5}{|c|}{ 流水中の実騟条件 } \\
\hline & $\varepsilon_{0}$ & $\mathrm{U}(\mathrm{cm} / \mathrm{s})$ & $W_{0}\left(\mathrm{~cm}^{3} / \mathrm{s}^{2}\right)$ & $A_{0}\left(\mathrm{~cm}^{2}\right)$ \\
\hline case 1 & \multirow{9}{*}{0.26} & \multirow{3}{*}{1.49} & 101.92 & 0.40 \\
\hline case2 & & & 146.51 & 0.58 \\
\hline case3 & & & 191.10 & 0.75 \\
\hline case 4 & & \multirow{3}{*}{4.94} & 101.92 & 0.40 \\
\hline case5 & & & 146.51 & 0.58 \\
\hline case 6 & & & 191.10 & 0.75 \\
\hline case7 & & \multirow{3}{*}{6.45} & 101.92 & 0.40 \\
\hline case8 & & & 146.51 & 0.58 \\
\hline case9 & & & 191.10 & 0.75 \\
\hline case10 & \multirow{9}{*}{0.38} & \multirow{3}{*}{1.56} & 102.41 & 0.28 \\
\hline case11 & & & 148.96 & 0.40 \\
\hline case 12 & & & 195.51 & 0.53 \\
\hline case13 & & \multirow{3}{*}{4.97} & 102.41 & 0.28 \\
\hline case 14 & & & 148.96 & 0.40 \\
\hline casel5 & & & 195.51 & 0.53 \\
\hline case16 & & \multirow{3}{*}{6.35} & 102.41 & 0.28 \\
\hline case17 & & & 148.96 & 0.40 \\
\hline case 18 & & & 195.51 & 0.53 \\
\hline
\end{tabular}

してW。が通りになるようにA 一様流速Uを3通りに変化させた。

一様流の設定は、まず流量を調節し、各断面での 流速差をなくすためにハニカムを設置するとともに、 水路下流端に取り付けられた複数のバルブを微調節 することによって行なった。また、流下方向に3点、 落下方向に 4 点の計 12 点を電磁流速計で測定すると ともに、アニリンブルー染料を用いて一様流速の確 認を行なった。

\section{3. 実験結果}

図2の(a)、(b)は、case11 (U=1.56 cm / s、 $\varepsilon_{0}=$ 


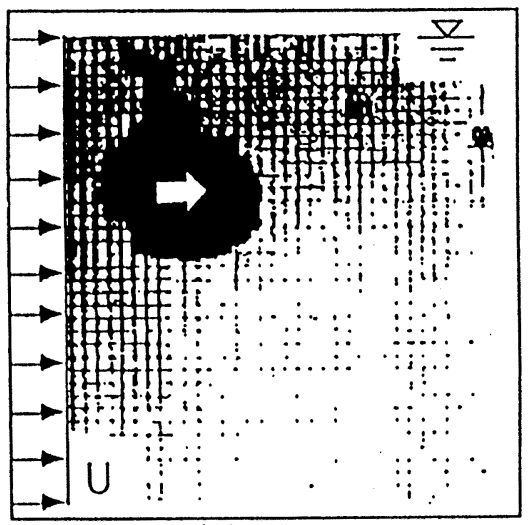

(a) $t=6 s$

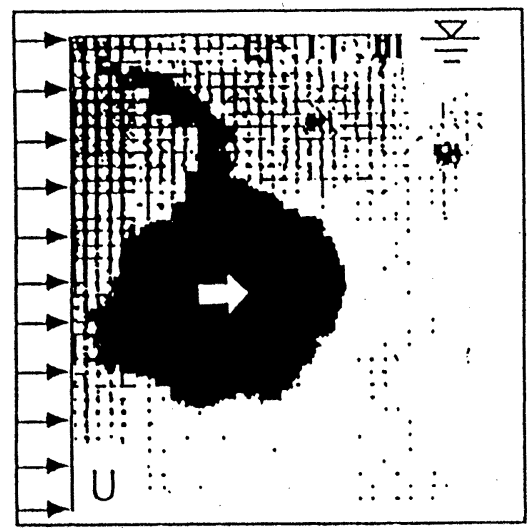

(b) $\mathrm{t}=14 \mathrm{~s}$

図-2 流況 (case11)

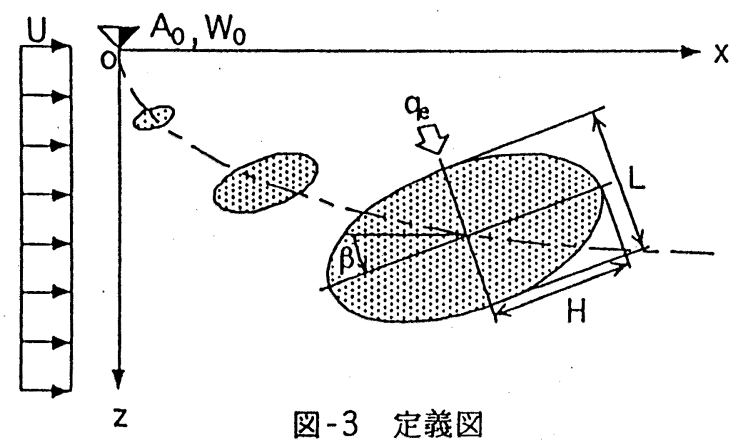

0.38、 $\left.\mathrm{W}_{0}=148.96 \mathrm{~cm}^{3} / \mathrm{s}^{2}\right)$ の流況を示したものであ る。これより、塩水塊が㑬国流体を活発に連行しつ つ、傾き角度 $\beta$ のやや左下がりで発達していく様子 がわかる。そこて、一様流中を落下する2次元塩水 塊を図3のようにモデル化して考える。

以下に実験結果について検討を加える。ただし、 得られた各特性量は初期相対密度差 $\varepsilon_{0} に は$ 傾向的に 依存せず、塩水塊の軌跡を除く各特性量は一様流速 Uにも傾向的に依存しないことが認められたので、 以下では各特性量と初期総有効重力W 0 との関係に ついて考察する。

\section{（1）落下㦈水塊の無次元形状、傾き角度 $\beta$ およひ 軌跡}

塩水塊の然次元形状の一例と傾き角度 $\beta$ を図 4 、

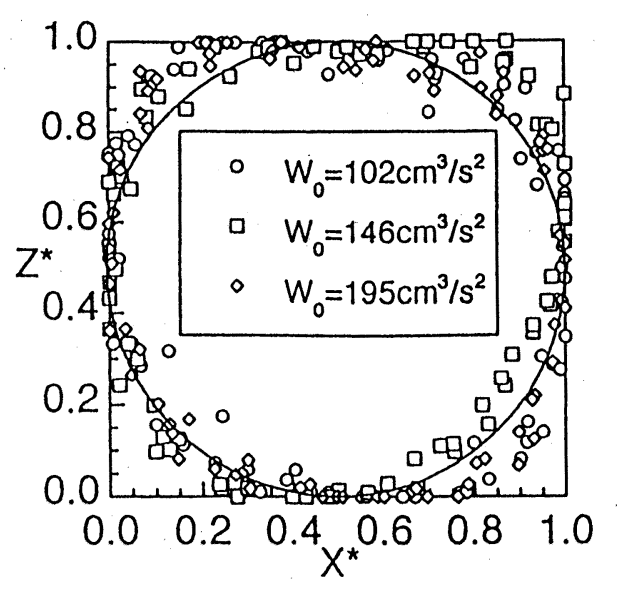

图-4 塩水塊の無次元形状

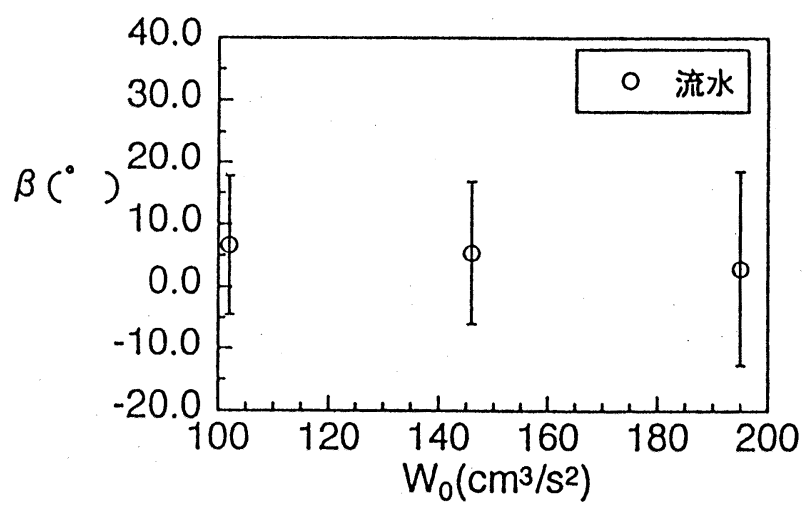

图-5 塩水塊の傾き角度 $\beta$

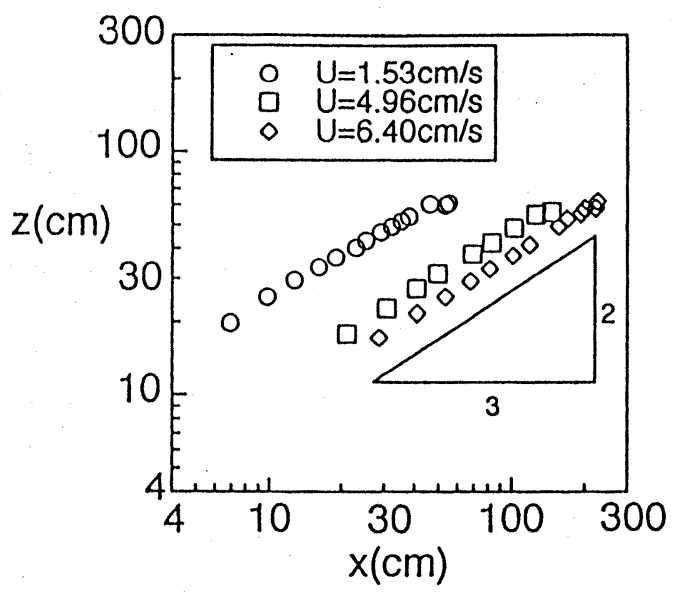

図-6 塩水塊の重心の軌跡

5にそれぞれ示す。図4では、形状を幅方向にH、長 さ方向にLで正規化して表示してある。両図より、 塩水塊はほぼ棈円形状の相似形を保ちながらW。に 傾向的に依存せす流水中を発達していくが、その際、 平均的にほぼ6 の角度で傾きながら落下していく ものの傾き角度は大きく変動することがわかる。

図6は塩水塊の重心の軌跡を示したものである。 当然のことながら塩水塊の軌跡については一様流速

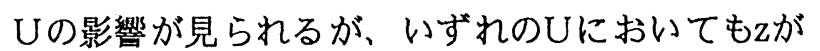




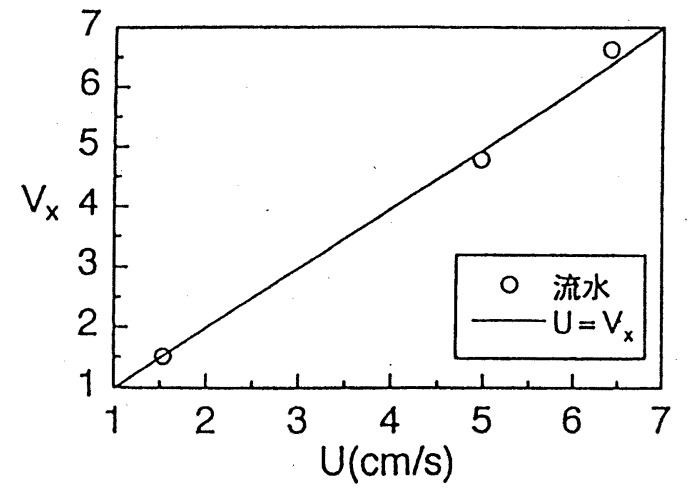

図-7 $\mathrm{V}_{\mathrm{X}}$ とUとの関係

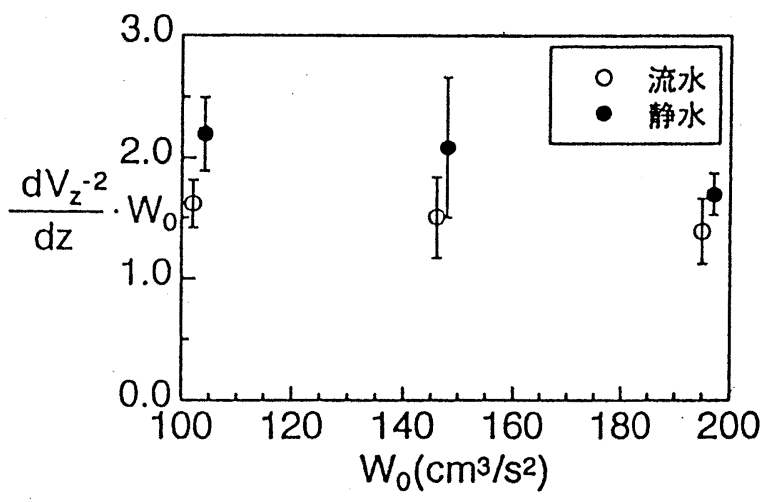

図-8 $\left(\mathrm{dV}_{\mathrm{z}}^{-2} / \mathrm{d} z\right) \cdot \mathrm{W}_{0}$ と $\mathrm{W}_{0}$ との関係

$\mathrm{x}^{2 / 3}$ に比例することがわかる。この理由は、後述す るように、静水中では落下速度 $V_{z}$ はV $V_{z}=\mathrm{z} / \mathrm{t} \sim \mathrm{Z}^{-1 / 2}$ なる関係を有することからた〜 $\mathrm{Z}^{3 / 2}$ となるが、水平移 動速度 $V_{x}$ はV $V_{x}=x / t=-$ 定なる関係を有することか ら $\mathrm{x}$ 七となる。これより からであると考えられる。

\section{（2）重心の水平移動速度 $V_{\mathrm{x}}$ および落下速度 $\mathrm{V}_{\mathrm{z}}$}

重心の水平移動速度 $V_{x}$ と一様流速Uとの関係を 図7に示す。これより、 $\mathrm{V}_{\mathrm{x}}$ とUとの值がほぼ完全に 一致しており、塩水塊は流入条件に依存せず、ほぼ 周囲流体の一様流速Uで移流されることがわかる。 また、このような傾向は小田ら ${ }^{5)}$ の数值計算でも報 告されている。

静水中における塩水塊の落下速度 $V_{2}$ は落下距離 $Z$ に対して $z^{-1 / 2}$ なる関係があることが理論的・実験的 にわかっているが、流水中の塩水塊の落下速度 $V_{z}$ についてもややばらつきは認められるものの、 $\mathrm{V}_{z}$ 〜 $z^{-1 / 2}$ なる関係がほぼ成立することが確認された。 そこて、、流水中の $\mathrm{V}_{\mathrm{z}}^{-2}$ の無次元変化率 $\left(\mathrm{dV}_{\mathrm{z}}{ }^{-2} / \mathrm{dz}\right)$ ・ $\mathrm{W}_{0}$ とW $\mathrm{W}_{0}$ との関係を調べ、静水中のものと比較検討 したものが図8である。以下の静水中と流水中の比 較の図では、W

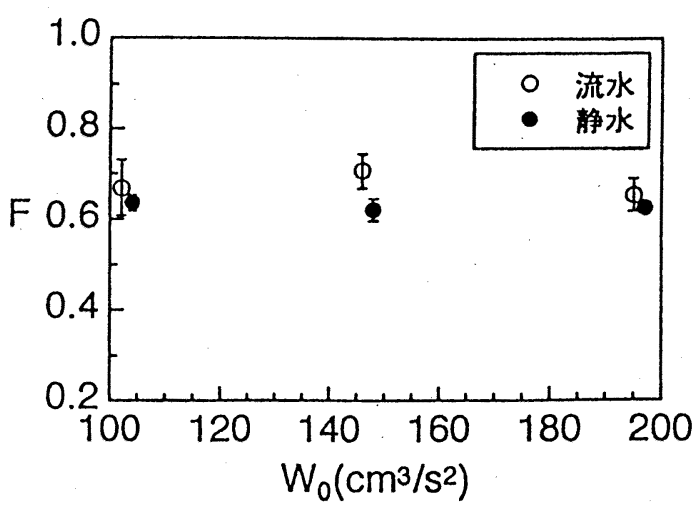

图-9 FとW $\mathrm{F}_{0}$ との関係

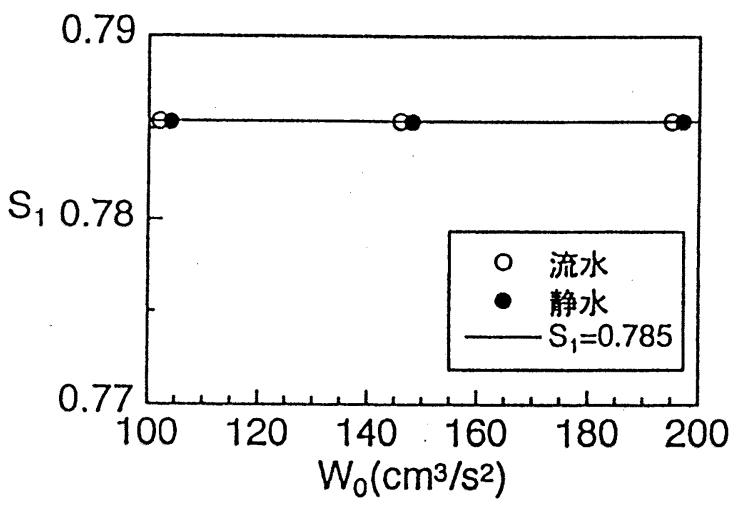

図-10 $\mathrm{S}_{1}$ と $\mathrm{W}_{0}$ との関係

同図より、 $\mathrm{V}_{z}$ の変化率は流水中の方が大きく、流 水中の場合の方が早く落下することがわかる。これ

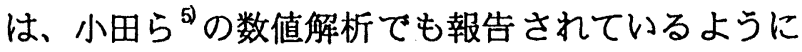
流水中では循環流の発達が妨げられることが理由で あると考えられる。また、流水中と静水中のいずれ も列が増加すると $\mathrm{V}_{\mathrm{z}}^{-2}$ の変化率が減少することより、 $\mathrm{V}_{\mathrm{z}}$ の変化率はW かる。これは、W われるためであると考えられる。

\section{（3）断面アスペクト比Fおよび断面面積比 $S_{1}$ 之初 期総有効重力W 0 との関係}

式(1)と(2)でそれぞれ定義される断面アスペクト 比Fおよび断面面積比 $\mathrm{S}_{1}$ と $\mathrm{W}_{0}$ との関係を図 9 と 10 に それぞれ示す。これより、流水中に比べ静水中の場 合のFがやや小さい值となっていることから、静水 中ではやや丸まった形状を取ることや流水中では形 状がかなり変動することなどがわかる。図 9 より、 流水中のFは式(3)で近似できる。

$\mathrm{S}_{1}$ は流水中と静水中で違いはなく、 $\mathrm{W}_{0}$ にも傾向 的に依存しないことが認められる。また、その值は 式(4)で近似され、楕円形状の $S_{1}$ 値である $\pi / 4(\fallingdotseq$ 0.785)にほぼ等しい。 


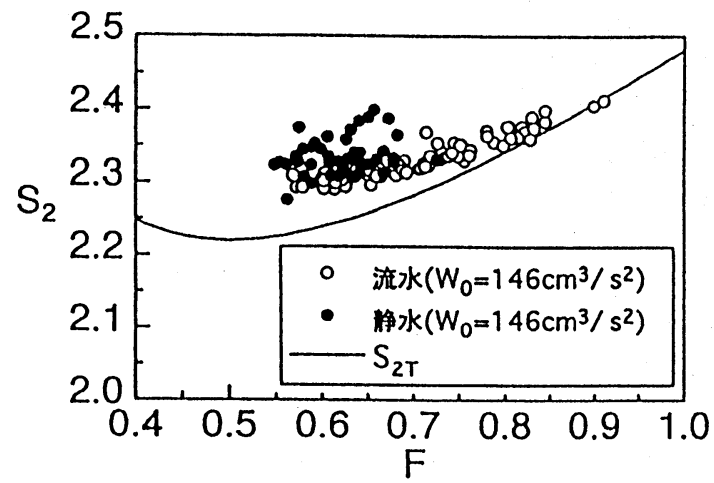

図-11 $\mathrm{S}_{2}$ とFとの関係
$\mathrm{F}=\frac{\mathrm{H}}{\mathrm{L}}$
(1) ; $\mathrm{S}_{1}=\frac{\mathrm{A}}{\mathrm{HL}}$
$\mathrm{F}=0.677 \pm 0.027$
(3) $; S_{1}=0.785$

(4)

（4）周囲長に関する形状係数 $\mathrm{S}_{2}$ と断面アスペクト 比との関係

式(5)で定義される塩水塊の幾何学的平均長さ $\sqrt{\mathrm{HL}}$ と周囲長 $\mathrm{C}$ と比である $\mathrm{S}_{2}$ と $\mathrm{F}$ との関係の一例 $\left(\mathrm{W}_{0}=146 \mathrm{~cm}^{3} / \mathrm{s}^{2}\right)$ を図 11 に示す。なお、図中の曲線 は式(6)で与えられる楕円形状の場合の $\mathrm{S}_{2 \mathrm{r}}$ を表示し たものである。これより、流水中では円形に近い形 状から楕円形状までの幅広い形を取り得ることやF が小さいところで $\mathrm{S}_{2}>\mathrm{S}_{2 \mathrm{~T}}$ であり、大きいところで $\mathrm{S}_{2}$ が $\mathrm{S}_{2 \mathrm{~T}}$ に近くなることが認められる。これは高密 度の重い流体を瞬間的に投下すると、塩水塊は投下 直後では、縦脣の楕円形状となるか落下とともに徐々 に発達変形し円形状に近づいていくためである。ま た、㙁水塊がある程度発達した状態では一般的に $\mathrm{S}_{2}>$ $\mathrm{S}_{2 \mathrm{~T}}$ となる傾向が認められる。

$$
\begin{gathered}
S_{2}=\frac{C}{\sqrt{\mathrm{HL}}} \\
S_{2 \pi}=\frac{\pi}{2^{32}} \cdot \frac{\sqrt{4 \mathrm{~F}^{2}+1}}{\sqrt{\mathrm{F}}}
\end{gathered}
$$

（5）層厚变化率 $\mathrm{dH} / \mathrm{d}$ 拉よび平均浮力B の無次元 变化率 $\left(\mathrm{dB}^{-1 / 2} / \mathrm{dz}\right)^{2} \cdot \mathrm{W}_{0}$ 之初期総有効重力 $\mathrm{W}_{0}$ 亡の関係

層厚変化率 $\mathrm{dH} / \mathrm{dz}$ と $\mathrm{W}_{0}$ との関係を図12に示す。 これより、 $\mathrm{W}_{0}=146 \mathrm{~cm}^{3} / \mathrm{s}^{2}$ においてはややばらつき が認められるが、静水中と流水中のいずれもW 増加とともに $\mathrm{dH} / \mathrm{d} z$ 減少する傾向が認められる。 これは、 $\mathrm{W}_{0}$ が大きいと縦長の楕円形状となり十分 に発達しないままに着底してしまうためである。実 際の直投工では、通常、経済性の立場から濁水塊が 十分に発達するような深い水深下で土砂の投下が行 なわれることはない。従って、実際問題では投下後

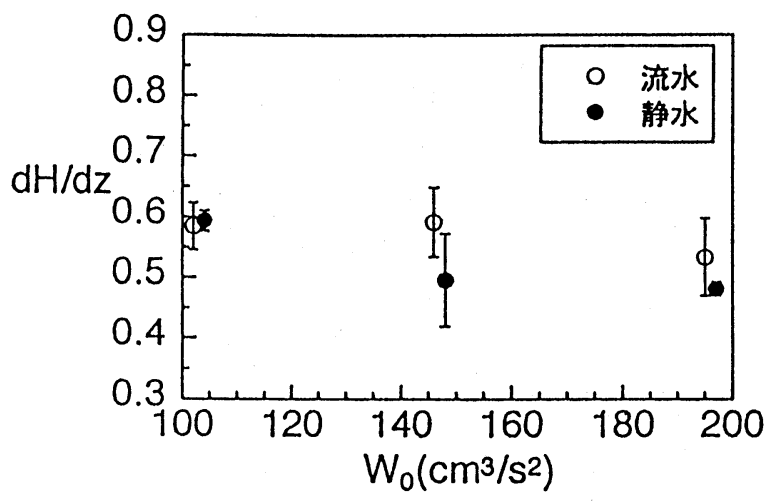

図-12 $\mathrm{dH} / \mathrm{dz}$ とW $\mathrm{W}_{0}$ との関係

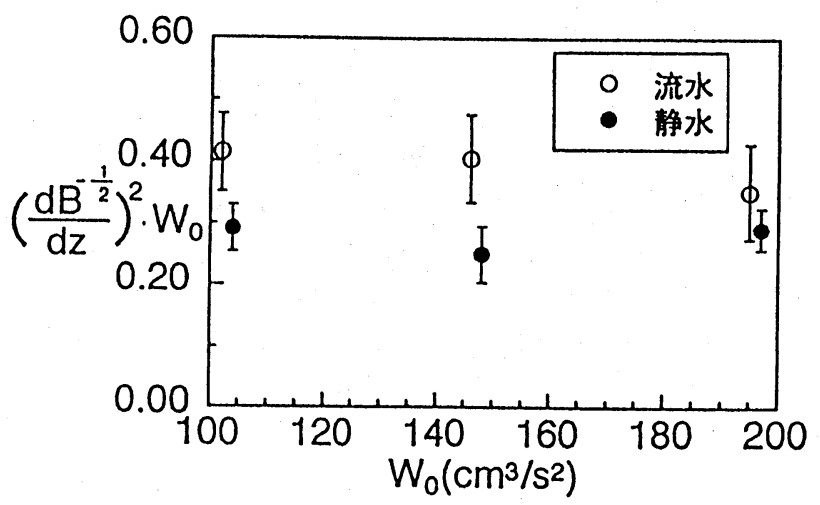

图-13 $\left(\mathrm{dB}^{-1 / 2} / \mathrm{dz}\right)^{2} \cdot \mathrm{W}_{0}$ と $\mathrm{W}_{0}$ との関係

の塩水塊の挙動は初期総有効重力W 0 によって大き く支配されると思われる。

初期総有効重力 $\mathrm{W}_{0}$ が保存されることより平均浮 力Bを式(7)より算出することができ、流水中と静水 中のいずれも落下距離 $に$ 対してB〜 $\mathrm{Z}^{-2}$ なる依存性 があることが認められた。そこで、塩水塊のB ${ }^{-1 / 2}$ の 無次元変化率 $\left(\mathrm{dB}^{-1 / 2} / \mathrm{d} z\right)^{2} \cdot \mathrm{W}_{0}$ と $\mathrm{W}_{0}$ との関係を示し たものが図13である。これより、Bの変化率は流水 中の方が小さく、周囲流体の連行による希釈作用が より小さいことがわかる。また、流水中と静水中の いずれも和が增吅すると、 $\mathrm{dB}^{-1 / 2} / \mathrm{d} z$ は诚少する傾 向が認められるが、これはV $\mathrm{V}_{z}$ の変化率でも述べた ようにW めであると考えられる。

$$
B=\frac{W_{0}}{A}
$$

\section{（6） 連行係数 $E_{d}$ と初期総有効重力 $W_{0}$ との関係}

ある瞬間の連行係数 $\mathrm{E}_{\mathrm{d}}{ }^{\prime}$ は、連行量 $\mathrm{q}_{\mathrm{e}}$ をある瞬間 の塩水塊の断面積 $\mathrm{A}$ の変化率 $\Delta \mathrm{A} / \Delta \mathrm{t}$ より算出する

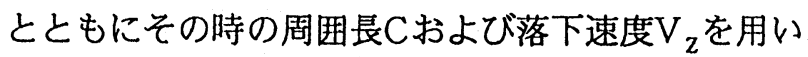
て式(8)より求められる。 $E_{\mathrm{d}}{ }^{\prime}$ の頻度分布の一例を図 14 に示す。さらに、 $\mathrm{E}_{\mathrm{d}}{ }^{\prime}$ 值の集合平均をとることに 


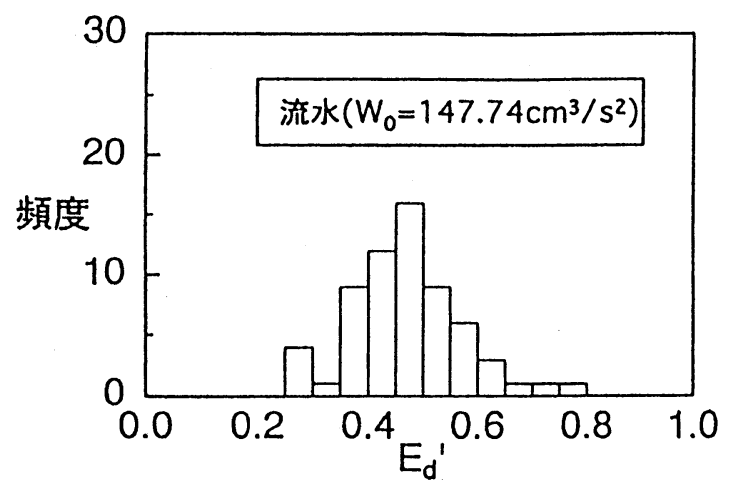

图-14 $\mathrm{E}_{\mathrm{d}}{ }^{\prime}$ の頻度分布

より平均的な $\mathrm{E}_{\mathrm{d}}$ を算定することができる。このよう にして得られた $\mathrm{E}_{\mathrm{d}}$ とW $\mathrm{W}_{0}$ との関係を示したものが図 15である。これより、流水中の塩水塊の連行係数 $\mathrm{E}_{\mathrm{d}}$ はW 6 に対しては傾向的には依存せず、式(9)で近 似できることがわかる。また、静水中では $\mathrm{E}_{\mathrm{d}} \fallingdotseq$ 0.505 であるので、静水中に比べ流水中の方が $10 \%$ 程度小さい値を取る。これは流水中では循環流が静 水中のように発達しないため、連行量が減少したた めであると考えられる。

$$
E_{d}=\frac{q_{e}}{C V_{z}} \quad(8) \quad ; \quad E_{d}=0.455 \pm 0.007
$$

\section{4. まとめ}

本研究によって以下のような結論が得られた。

（1）流水中の塩水塊は左右非対称でほぼ棈円形状 の相似形であるが、形状と傾き角度を大きく変 動させながら流水中を落下する。

（2）流水中の塩水塊はほぼ一様流速 $\mathrm{U}\left(\fallingdotseq \mathrm{V}_{\mathrm{x}}\right)$ で移 流され、落下速度 $\mathrm{V}_{2}$ については静水中之同様 に $\mathrm{V}_{\mathrm{Z}} \sim Z^{-1 / 2}$ なる関係がほぼ成立する。その結果、 塩水塊の轨跡には 2 ～ $\mathrm{x}^{2 / 3}$ なる関係が成立する。

（3）流水中の塩水塊では循環流の発達が妨げられ るため、静水中に比べ連行が弱くなり塩水塊の 断面積の增加率が小さくなる。従って、平均浮 力Bの減少率も小さくなる。また、同様の理由、 でその落下速度も静水中より大きくなる。

（4）塩水塊では静水中と流水中いずれも平均浮力 $\mathrm{B}$ と落下速度 $\mathrm{V}_{2}$ は初期総有効重力 $\mathrm{W}_{0}$ に強く依 存する。また、W $\mathrm{W}_{0}$ が大きいほど連行量が增加 するため、Bの減少率と $\mathrm{V}_{\mathrm{z}}$ の変化率は大きくな る。

（5）流水中の塩水塊の連行係数 $\mathrm{E}_{\mathrm{d}}$ は、循環流が静 水中のように発達しないため、静水中よりも 10\%ほど小さい値となる。

最後に、流水中の濁水塊の挙動予測への相似形状

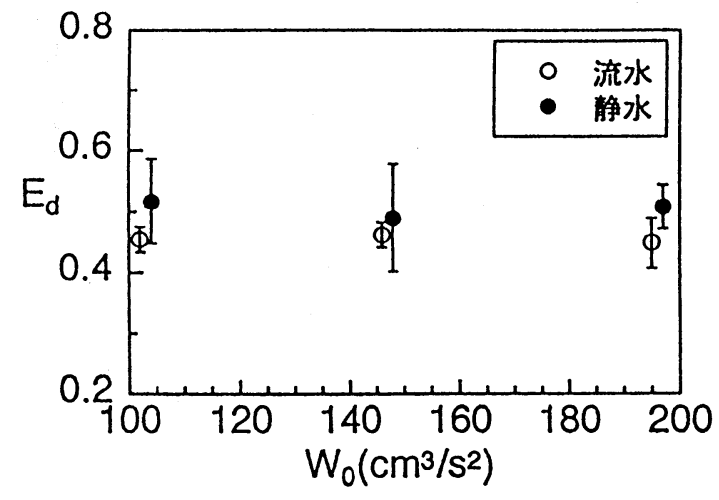

図-15 $E_{d}$ とW 0 との関係

に基づく理論モデルの適用性についてであるが、断 面アスペクト比や傾き角度などが変動しながら落下 することが本現象の大きな特徽であるが、形状が相 似形であることや水平移動速度、落下速度、轨跡、 連行係数などの特性量がかなりの精度で定量化でき ることなどから、かたまりとして捉えた平均的な流 動特性の予測についてはそのようなモデルの適用が 可能であると思われる。

今後は、流水中の塩水塊の相似形状に基づく理論 モデルの構築や乱流モテルを用いた数值解析などを 行ない、理論的な側面から検討を加えていく予定で ある。

謝辞 : 本研究の一部は、文部省科学研究費、(代表 者 : 秋山壽一郎、課題番号08455232）の援助を受 けた。ここに記して感謝の意を表します。

\section{参考文献}

1）玉井昌宏、村岡浩爾、室田明：固体粒子群の落下挙動 と䇋起流動に関する研究、土木学会論文集、No.509/ II-30、pp.143-154、 1995.

2) Baines, W.D \& Hopfinger, E.J. : Thermals with large density difference, Atomospheric Enviroment, Vol. 18, Number 6,1984.

3) Escudier, M.P. \& Maxworthy, T. : On the motion of turbulent thermals, J. Fluid Mech, Vol. 61, part 3, pp. 541-552,1973.

4）小田一紀、重松孝昌、大西伸幸、井上雅夫：改良型 DEMAC法による粒子群の沈降・分散挙動の解析、海 岸工学論文集、第39巻、pp.971-975、1992.

5）小田一紀、重松孝昌、督野 寛: 粒子群の沈降・分散 挙動に及ぼす流れの影響に関する数值実験、海岸工学 論文集、第42巻、pp.1271-1275、1995.

6) 例えば、秋山尋一郎、浦 勝、応晋严、今宮盛雄、陶 山正治 : 静水中に瞬間的に投下された重たい流体塊の 流動特性に関する研究、水工学論文集、第 42 巻、 1998.

(1997.9. 30 受付) 